\title{
Comparison of the Degradation of the Polarization Resistance of Symmetrical LSM- YSZ Cells, with Anode Supported Ni-YSZ/YSZ/LSM-YSZ SOFCs
}

Torres da Silva, Iris Maura; Nielsen, Jimmi; Hjelm, Johan; Mogensen, Mogens Bjerg

Published in:

Meeting Abstracts - Electrochemical Society

Publication date:

2009

Document Version

Publisher's PDF, also known as Version of record

Link back to DTU Orbit

Citation (APA):

Torres da Silva, I. M., Nielsen, J., Hjelm, J., \& Mogensen, M. B. (2009). Comparison of the Degradation of the Polarization Resistance of Symmetrical LSM-YSZ Cells, with Anode Supported Ni-YSZ/YSZ/LSM-YSZ SOFCs. In Meeting Abstracts - Electrochemical Society (pp. Abstract 1508). The Electrochemical Society.

\section{General rights}

Copyright and moral rights for the publications made accessible in the public portal are retained by the authors and/or other copyright owners and it is a condition of accessing publications that users recognise and abide by the legal requirements associated with these rights.

- Users may download and print one copy of any publication from the public portal for the purpose of private study or research.

- You may not further distribute the material or use it for any profit-making activity or commercial gain

- You may freely distribute the URL identifying the publication in the public portal 


\section{Comparison of the degradation of the polarisation resistance of symmetrical LSM-YSZ cells, with anode supported Ni-YSZ/YSZ/LSM-YSZ SOFCs}

$\underline{\text { Iris M. Torres da Silva, Jimmi Nielsen, Johan Hjelm and }}$ Mogens Mogensen

Fuel Cells and Solid State Chemistry Division, Risø National Laboratory for Sustainable Energy, Technical University of Denmark

Frederiksborgvej 399, DK-4000 Roskilde, Denmark

Symmetrical cells are a useful tool for screening electrode performance [1]. The goal of this study was to investigate how the results collected from symmetrical cells relate to results obtained on a corresponding full cell. Therefore, electrochemical impedance spectra (EIS) from a symmetrical cell and full cell were collected periodically over a longer period of time, at open circuit voltage. The operating conditions were chosen such that no degradation of the anode is expected and parameters were varied within the limits of realistic operating conditions.

The symmetrical cells were screen-printed lanthanum strontium manganite - yttria stabilized zirconia composite cathodes [LSM25.5-YSZ composites, where LSM25.5 = $\left(\mathrm{La}_{0.75} \mathrm{Sr}_{0.25}\right)_{0.95} \mathrm{MnO}_{3 \pm \delta}$ and $\mathrm{YSZ}=\mathrm{ZrO}_{2}$ with $8 \mathrm{~mol} \%$ $\left.\mathrm{Y}_{2} \mathrm{O}_{3}\right]$ on stabilized zirconia, YSZ, electrolyte. The full cells were planar anode supported $\mathrm{Ni}$ -

YSZ/YSZ/LSM25.5-YSZ cells. These materials have been chosen as they are of continuing interest in the field $[1,2,3]$

The EIS data of the symmetrical and full cells were modelled using appropriate equivalent circuits $[4,5]$. Using these models the influence of varying operation conditions was determined, providing information on what frequency range is affected by which physical process. Furthermore, the degradation rates of the polarisation resistance $\left(\mathrm{R}_{\mathrm{p}}\right)$ at different operating conditions were determined.

Further analysis techniques like ADIS [6] (analysis of difference in impedance spectra) and DRT [7]

(distribution of relaxation times) were applied to check whether the degradation of $R_{p}$ of the full cell was due to the cathode and the cathode/electrolyte interface and not to the anode. Finally the degradation rates of $R_{p}$ of the full and symmetrical cell were compared.

\section{References}

[1] S.C Singhal and K. Kendall, editors. High Temperature Solid Oxide Fuel Cells - Fundamentals, Design and Applications. Elsevier, 2003.

[2] S.P. Jiang. J. Mater. Sci. 43:6799, 2008.

[3] S.B. Adler. Chem. Rev. 104:4791, 2004.

[4] M.J. Jørgensen, S. Primdahl, C. Bagger, and M. Mogensen. Solid State Ionics, 139:1, 2001.

[5] R. Barfod, A. Hagen, S. Rasmousse, P.V. Hendriksen, and M. Mogensen. Fuel Cells, 6:141, 2006.

[6] S.H. Jensen, A. Hauch, P.V. Hendriksen, M.

Mogensen, N. Bonanos, and T. Jacobsen. Journal of the Electrochemical Society, 152:B1325, 2007.

[7] H. Schichlein, A. Müller, M. Voigts, A. Krügel, and E. Ivers-Tiffée. Journal of Applied Electrochemistry, $32: 875,2002$ 